\title{
Genetic Study
}

National Cancer Institute

\section{Source}

National Cancer Institute. Genetic Study. NCI Thesaurus. Code C84431.

An examination of genetic material for the presence or absence of cytogenetic or molecular genetic abnormalities. 